\title{
情報がおいしさに及ぼす影響
}

豊満美峰子*・小宮麻衣良*・松本 仲子**

(*杉野服飾大学, **女子栄養大学)

\section{Influence of the informational factors on the taste}

\author{
*Mioko Toyomitsu, *Maira Komiya, ${ }^{* *}$ Nakako Matsumoto \\ *Sugino Fashion College, 4-6-19 Kamiohsaki Shinagawa-ku Tokyo, 141-8652 \\ **Kagawa Nutrition University, 3-9-21 Chiyoda Sakado-shi Saitama, 350-0288
}

干141-8652 東京都品川区上大崎 4-6-19

厂350-0288 埼玉県坂戸市千代田 3-9-21

In this study, we observed how evaluations of taste change when information is disclosed about the food being evaluated. The information included price, product name, production region, nutritional additives, genetic modifications, and cultivation methods. Tests with and without information disclosure were separately conducted, one month apart, in order to ensure that the evaluations were independent.

Evaluation of the effects of the disclosure vs. nondisclosure of prices showed that lower prices downgraded the evaluations while higher prices increased the evaluations. With regard to the product name,the evaluations tended to increase in proportion to the brand rating of the products. Well-known production regions received higher evaluations for domestic products, while domestic products received higher evaluations than foreign products in all instances. When information regarding nutritional additives, such as iron, calcium, and B-complex vitamins was disclosed, the evaluations tended to decrease. The evaluations of products which contained no genetically modified ingredients were higher than those of products with no information about genetic modifications, which in turn were higher than those of products indicating the use of genetically modified ingredients. Information such as few added chemicals, chemically - free, and organic increased the evaluations. Approximately $56 \%$ of all the products showed a significant change in the taste evaluation following the disclosure of information about the food.

\section{1. 緒論}

食物のおいしさは, 味や香りといった食物の特性自体 によって決まるのではなく，食べるひとの五感や情感が， 食物に関わる情報をどのように受容するかによって決定 づけられる。近年は, 食に関する膨大な情報が汇監し, それらもまたおいしさに影響を及ぼす大きな要因のひと つと考えられる。社会学の分野に沶いても，「フード. ファディズム」と呼ばれる購買行動についての研究1) 4) がなされて抢り, テレビなどで, ある食品についての栄 養学的情報が流布すると当該食品が売り切れてしまう, あるいは瘦身用のドリンク剤を常用して低栄養状態に陥
る若年女性の増加など, コマーシャルが惹起する社会的 問題が多々指摘されている。おいしさに関する情報も食 行動に与える影響は大きいものと推測され，報告例5) 9) も散見される。しかし食物のおいしさを測定する官能評 価法では，パネリストの主観的意識などの情報は努めて 排除されるため, 情感を含めた食物のおいしさについて の研究はなされてこなかった。

本研究では, 食物の情報がおいしさの印象に影響する か否かを明らかにすることを目的として実験を行った。 情報の内容は多岐にわたるが，ここでは食品選択に際し て重要と思われる価格と商品名を中心に産地, 購入場所, 添加物, 栄養成分, 遺伝子組久換え, 栽培方法の各項目 
情報がおいしさに及ぼす影響

表 1 実験に使用した食品/価格・商品名

\begin{tabular}{|c|c|c|}
\hline 食品の種類 & 商品名 & 価格 \\
\hline 䣫 & MK米酥 & 30 \\
\hline & MS自然酢 & 80 \\
\hline & KM T酢 & 117 \\
\hline & UJ特選本造 & 139 \\
\hline & SY国産有機 & 194 \\
\hline 塩 & $\mathrm{H}$ の塩 & 32 \\
\hline & A塩 & 111 \\
\hline & 中国 S 省岩塩 & 150 \\
\hline & ON天然塩 & 275 \\
\hline & M深層海水 & 400 \\
\hline 奨油 & Q㜔油 & 28 \\
\hline & Y奨油 & 29 \\
\hline & Y有機吟選 & 38 \\
\hline & S丸大豆 & 40 \\
\hline & Q 特選 & 42 \\
\hline 味増 & NK純正 & 60 \\
\hline & SS無添加 & 93 \\
\hline & NK天然醸造 & 120 \\
\hline & SS低温熟成 & 160 \\
\hline & MG無添加 & 176 \\
\hline 砂糖 & 三温糖 & 28 \\
\hline & T島 粗糖 & 60 \\
\hline & てんさい含蜜 & 70 \\
\hline & $\begin{array}{l}\text { 無農薬栽培 } \\
\end{array}$ & 160 \\
\hline & S 和三盆 & 231 \\
\hline みりん & ほんてり & 56 \\
\hline & T本みりん & 80 \\
\hline & 純米本搾り & 87 \\
\hline & 家醇 & 130 \\
\hline & MKみりん & 140 \\
\hline マヨネーズ & SBG & 30 \\
\hline & $\mathrm{KK}$ & 50 \\
\hline & $\mathrm{AJ}$ & 63 \\
\hline & $\mathrm{Q}$ & 76 \\
\hline ドレッシング & MC & 105 \\
\hline & SBG & 128 \\
\hline & $\mathrm{Q}$ & 139 \\
\hline & $\mathrm{E}$ & 166 \\
\hline & FS & 193 \\
\hline （飲料·菓子類） & & \\
\hline みかん缶詰 & IB & 21 \\
\hline & $\mathrm{CP}$ & 24 \\
\hline & HG & 64 \\
\hline & M屋 & 75 \\
\hline カステラ & X円均一 & 77 \\
\hline & $\mathrm{YZ}$ & 80 \\
\hline & $\mathrm{AJ}$ & 85 \\
\hline & $\mathrm{CP}$ & 142 \\
\hline & B堂 & 240 \\
\hline バームクーヘン & M品 & 85 \\
\hline & SYU & 95 \\
\hline & K屋 & 109 \\
\hline & MS屋 & 109 \\
\hline & UHM & 265 \\
\hline ポテトチップス & X円均一 & 93 \\
\hline & M品 & 136 \\
\hline & $\mathrm{CB}$ & 163 \\
\hline & 自然食品 & 167 \\
\hline オレンジジュース & MR & 15 \\
\hline & GR & 20 \\
\hline & TP & 26 \\
\hline & Pシシュース & 30 \\
\hline & AP & 111 \\
\hline （主食·惣菜・その他） & & \\
\hline ちくわ & スーパー & 65 \\
\hline & $\mathrm{CP}$ & 67 \\
\hline & NS & 79 \\
\hline & KB & 111 \\
\hline & デパート & 200 \\
\hline チーズ & YJ & 132 \\
\hline & SBG & 132 \\
\hline & MJ & 133 \\
\hline & 尃門店 F & 150 \\
\hline & $\mathrm{CP}$ & 198 \\
\hline きんぴら & スーパー & 168 \\
\hline & 打怱菜店 & 200 \\
\hline & デパート & 300 \\
\hline & KK & 405 \\
\hline 食パン & S-B & 98 \\
\hline & SYU & 128 \\
\hline & $\mathrm{MZ}$ & 150 \\
\hline & Tホテル & 336 \\
\hline & K屋 & 399 \\
\hline 牛乳 & $\mathrm{CP}$ & 198 \\
\hline & KW & 218 \\
\hline & YJ & 228 \\
\hline ヨーグルト & S-B & 28 \\
\hline & MJ & 47 \\
\hline & YJ & 48 \\
\hline & KW & 65 \\
\hline ジャム & KP & 61 \\
\hline & STN & 92 \\
\hline & AHT & 111 \\
\hline & SDFO & 165 \\
\hline & SF & 286 \\
\hline
\end{tabular}

表 2 実験に使用した食品/産地, 栄養成分 ·添加物, 遺伝子 組換え・栽培方法

\begin{tabular}{|c|c|c|}
\hline 食品の種類 & 情報内容 & 図用略名 \\
\hline \multirow[t]{3}{*}{ パイン缶 } & ハワイ産 & ハワイ \\
\hline & インドネシア産 & インドネシア \\
\hline & フィリピン産 & フィリピン \\
\hline \multirow[t]{2}{*}{ みかん缶 } & 中国産 & \\
\hline & 国産 & \\
\hline \multirow[t]{3}{*}{ りんご } & 青森県 & \\
\hline & 長野県 & \\
\hline & 記載なし & \\
\hline \multirow[t]{2}{*}{ リンゴジュース } & 輸入りんご使用 & 輸入 \\
\hline & 国産りんご使用 & 国産 \\
\hline \multirow{2}{*}{ オレンジジュース } & カリフォルニア（アメリカ） & カリフォルニア \\
\hline & 愛媛県（日本） & 愛媛県 \\
\hline \multirow{2}{*}{ ピーナッツ } & 中国産 & \\
\hline & 日本産 & \\
\hline \multirow[t]{2}{*}{ クッキー } & 外国産小麦使用 & 外国産 \\
\hline & 国産小麦使用 & 国産 \\
\hline \multirow[t]{3}{*}{ チョコレート } & ベルギー & \\
\hline & ベネズエラ & \\
\hline & 日本 & \\
\hline チーズ & 日本 & \\
\hline & ドイツ & \\
\hline & フランス & \\
\hline & デンマーク & \\
\hline & オーストラリア & \\
\hline 白飯（プランド） & 有機栽培米ごはん & 有機栽培 \\
\hline & UN 産コシヒカリ $100 \%$ & UN産 \\
\hline & ST Y産コシヒカリ & ST \\
\hline うずら豆（購入店） & スーパー & スーパー \\
\hline & 䑨菜チェーン & チェーン \\
\hline & デパート惣菜専門店 & デパート \\
\hline (添加物·栄養成分) & & \\
\hline ビスケット & 砂糖使用 & 砂糖 \\
\hline & 人工甘味料使用 & 人口甘味料 \\
\hline うずら豆 & 着色料使用していないの表示あり & 着色料表示有 \\
\hline & 着色料使用しているかの表示なし & 着色料表示無 \\
\hline コーンフレーク & 栄養成分添加なし & 添加なし \\
\hline & 鉄分添加 & 鉄分添加 \\
\hline ヨーグルトドリンク & 添加なし & 添加なし \\
\hline & 鉄分添加 & 鉄分添加 \\
\hline ウエハース & 添加なし & 添加なし \\
\hline & 鉄 $(\mathrm{Fe})$ 強化 & 鉄強化 \\
\hline 飲むヨーグルト & 添加なし & 添加なし \\
\hline & カルシウム強化 & Ca强化 \\
\hline 牛乳 & 添加なし & 添加なし \\
\hline & カルシウム強化 & Ca強化 \\
\hline シュークリーム & 添加なし & 添加なし \\
\hline & カルシウム強化 & Ca强化 \\
\hline タマゴボーロ & 添加なし & 添加なし \\
\hline & $\mathrm{B}_{1} \mathrm{~B}_{2}$ 添加あり & VB類添加 \\
\hline 卵 & 遺伝子組換えなしＰHFコーン主体 & PHFコーン \\
\hline & 海草粉末等強化 良質なヨードを含む & 海藻・ヨード \\
\hline & アスタキサンチンとビタミンDを含む & VD \\
\hline & DHAとビタミンEを含む & $\mathrm{DHA} \cdot \mathrm{VE}$ \\
\hline & 記載なし & 記載なし \\
\hline (遺层子組換え・栽培 & & \\
\hline コーン & 遺伝子組換えではないと表示 & 組み替え無 \\
\hline & 表示なし & 表示なし \\
\hline 大豆 & 遺伝子組み換え有りと表示 & 組久替え有 \\
\hline & 遺伝子組換えではないと表示 & 組及換え無 \\
\hline トマトケチャップ & 遺厷子組換えではないと表示 & 組み換え無 \\
\hline & 表示なし & 表示なし \\
\hline ポップコーン & 遺层子組換えではないと表示 & 組み換え無 \\
\hline & 表示なし & 表示なし \\
\hline ポテトチップス & 遺伝子組換えではないと表示 & 組队換え無 \\
\hline & 表示なし & 表示なし \\
\hline 冷凍枝豆 & 遺伝子組換えではないと表示 & 組久換え無 \\
\hline & 表示なし & 表示なし \\
\hline 餡 & 遺层子組換えではないと表示 & 組及換え無 \\
\hline & 表示なし & 表示なし \\
\hline コーンスナック & 遺伝子組換えではないと表示 & 組み換え無 \\
\hline & 表示なし & 表示なし \\
\hline ようかん & 遺伝子組換えではないと表示 & 組久換え無 \\
\hline & 表示なし & 表示なし \\
\hline ミニトマト & 隇農薬卜マト & 減農薬 \\
\hline & 表示なし & 表示なし \\
\hline かほちゃの煮物 & 無農薬有機野菜 & 無農薬有機 \\
\hline & 農薬使用野菜 & 農薬使用 \\
\hline & 表示なし & 表示なし \\
\hline
\end{tabular}


についても検討し，その結果，いくつかの知見を得たの で報告する。

\section{2. 実験方法}

\section{（1） 評価対象情報}

価格と商品名の官能評価（以下価格·商品名）で取り 上げた食品は, 調味料, 飲料·菓子類, 主食·惣菜その 他で，表 1 の通りである。また産地，購入場所，添加物， 栄養成分，遺伝子組久換え，栽培方法で取り上げた食品 は表 2 の通りである。全ての食品はパネルメンバー全員 が一様に認知していることを確認している。

\section{（2）官能評価の方法}

評価は官能検査台の上に置いた試料を目視して判断さ せた。目視による評価の信憑性を確認するために, 価格 . 商品名では食パンとヨーグルトの 2 品については試食も 行った。

\section{(1) 回 数}

評価回数は価格·商品名については 3 回行った。1 回 目は情報を与えずアルファベットの記号のみを付し（以 下，無情報)，2 回目は価格を明示（以下，価格明示)， 3 回目は商品名を明示（以下，商品名明示）した。1， 2，3 回の各評価が独立して行えるように，ほぼ 1 ヶ月 ずつの間隔をおいて行った。産地, 購入場所, 添加物, 栄養成分，遺伝子組久換え，栽培方法については 2 回行 った。1 回目は情報を与えずアルファベットの記号のみ を付し (以下，無情報），2 回目は情報を明示（以下， 情報明示）した。

\section{(2) 評価方法}

目視の結果，おいしさをどのように感じるかを「非常
においしそう」〜「非常にまずそう」の 7 段階で評価さ せた。また食パンとヨーグルトの試食した場合について は「非常においしい」〜「非常にまずい」の 7 段階で評 価させた。

試料提示の方法は, 固体の食品は白色プラスチック皿, 液体は透明ガラスコップに入れて供試した。

パネルは女子栄養大学短期大学部学生，18～20歳の女 性約60名である。

\section{3. 結果と考察}

7 段階の評価は，「非常においしそう」を3.0，「おい しそう」を2.0，「ややおいしそう」を1.0,「どちらでも ない」を 0 ，「ややまずそう」をー 1.0 ,「まずそう」を - 2.0，「非常にまずそう」をー3.00ように数值に置き 換え集計した。得られた評価の得点は，情報の有無及び 食品の品目を要因として二元配置の分散分析を行った。 その結果, 情報の有無間, ほぼ全ての食品の品目間ある いはその両者間に有意差が認められたので，各食品の評 価の平均值の差の検定を行った。

\section{A. 目視による評価 \\ (1) 価格明示の影響}

調味料一調味料の結果を図 1 に示した。図中の矢印は 無情報を基準として有意に評価が変動したことを示して いる。酢については，最も安価な 30 円が $0.1 \%$ 危険率， また最も高価な194円は 5 \%危険率で無情報より有意に 評価が高くなった。塩については最も安価な 32 円， 2 番 目に高価な275円は無情報より0.1\%危険率で有意に評価 が高くなった。奨油については，2 番目に安価な 29 円は 無情報より $0.1 \%$ 危険率で有意に高くなった。味噌につ

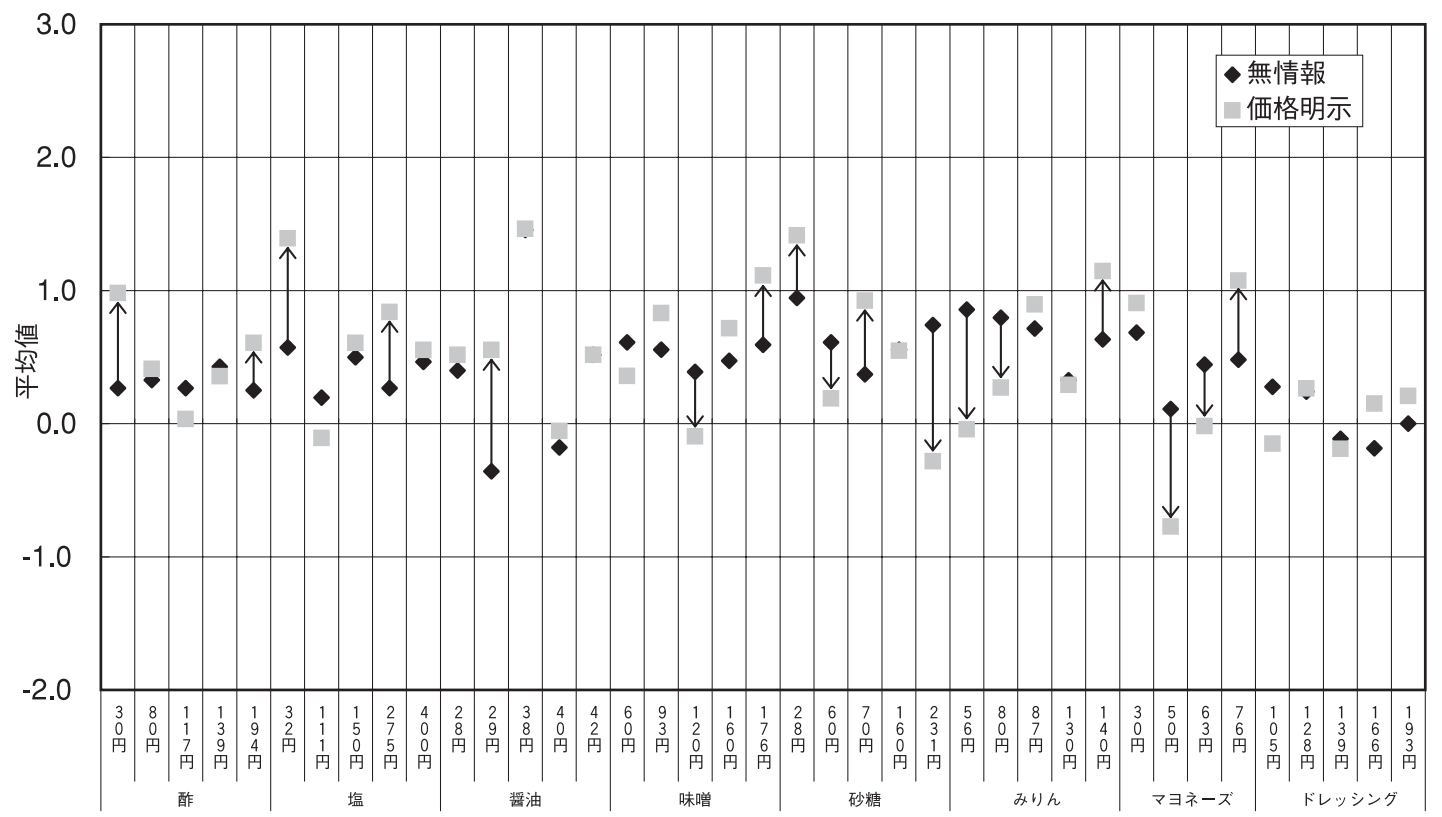

図 1 無情報と価格情報明示での評価の変動（調味料）

※矢印は無情報を基準にして有意に変動したことを示す 
いては，中間価格の 120 円が無情報より $5 \%$ 危険率で有 意に低く, 最も高価な176円は0.1\%危険率で無情報より 有意に評価が高くなった。砂糖については，無情報より 2 番目に安価な 60 円が $5 \%$ 危険率, 最も高価な 231 円が $0.1 \%$ 危険率で有意に評価が低くなった。また最も安価 な 28 円と中間価格の 70 円が $5 \%$ 危険率で無情報より有意 に評価が高くなった。みりんについては, 最も安価な56 円が $0.1 \%$ 危険率， 2 番目に安価な 80 円が $1 \%$ 危険率で 無情報より有意に評価が低くなった。最も高価な 140 円 は $5 \%$ 危険率で無情報より価格明示のほうが有意に評価 が高くなった。マヨネーズについては，50円が $1 \%$ 危険 率，63円が $5 \%$ 危険率で無情報より有意に評価が低くな った。また最も高価な76円は，1\%危険率で無情報より 有意に評価が高くなった。ドレッシングについては価格 は無情報と価格明示の間で有意な差は認められなかった。 調味料について価格を明示した場合の変化をまとめる と, 全般に安価なものは評価が低下し, 高価なものは評 価が高まる傾向がみられた。無情報と比較して価格明示 の評価が有意に低くなったのは味増 1 品, 砂糖 2 品, み りん 2 品, マヨネーズ 2 品の 4 品目 7 品, 有意に高くな った調味料は酢 2 品, 塩 2 品, 奨油 1 品, 味増 1 品, 砂 糖 2 品, みりん 1 品, マヨネーズ 1 品の 7 品目 10 品で, 調味料39品中情報によって評価が有意に変化したのは 17 品約 $44 \%$ であった。

飲料 · 菓子類一飲料 ·菓子類の結果を図 2 に示した。 無情報と比較して情報を明示したときは，みかん缶につ いては，安価な21円と24円が $1 \%$ 危険率で無情報よりは 有意に評価が低くなり，高価な 75 円は $0.1 \%$ 危険率で有
意に評価が高くなった。カステラについては 80 円が $5 \%$ ， 77円が 1 \%危険率で無情報より有意に評価が低くなり， 最も高価な240円が $0.1 \%$ 危険率で無情報より有意に評価 が高くなった。バームクーヘンについては最も安価な 85 円及び109円 b は $5 \%$ 危険率で無情報より有意に評価が 低くなった。109円は a ・ b の 2 種類あり若干外観が異 なるため，その影響で一方のみに評価の变動があったと 考えられた。265円は0.1\%危険率で有意に評価が高くな った。ポテトチップスについては, 無情報と比較して 2 番目に高価な 163 円が $5 \%$ 危険率で有意に評価が高くな った。オレンジジュースについては，26円が 1 \%危険率 で無情報より有意に評価が低く, 最も高価な 111 円が 0.1 \%危険率で有意に評価が高くなった。

飲料・菓子について価格を明示した場合の変化をまと めると, 最も安価なものは価格明示で評価が低くなり比 較的高価なものは価格明示で評価が高くなる傾向がみら れた。無情報と比較して価格明示の評価が有意に低くな ったのはオレンジジュース 1 品, カステラ 2 品, バーム

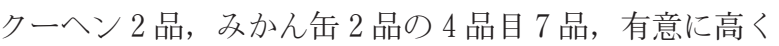
なったのはオレンジジュース 1 品, カステラ 1 品, バー

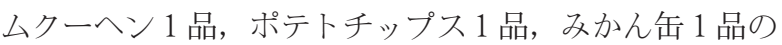
5 品目 5 品であった。23品中情報によって評価が有意に 変化したのは 12 品約 $52 \%$ であった。

主食·制菜·その他の食品一主食·䝆菜·その他の食 品の結果を図 3 に示した。ちくわについては, 最も安価 な65円が $1 \%$ 危険率で無情報より有意に評価が低くなっ た。最も高価な 200 円は $1 \%$ 危険率， 2 番目に高価な 111 円は $5 \%$ 危険率で有意に評価が高くなった。チーズでは,

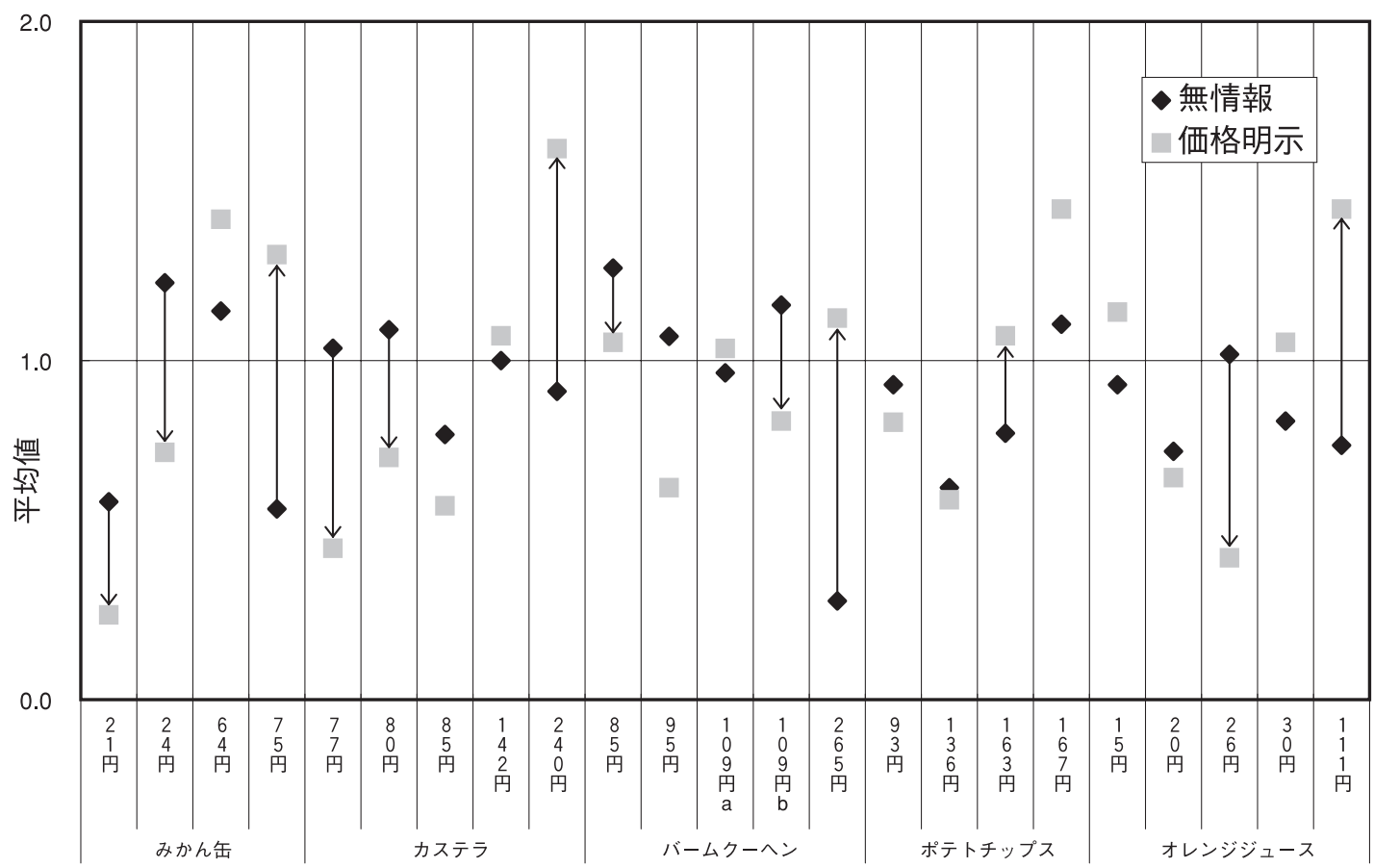

図 2 無情報と価格情報明示での評価の変動（飲料·菓子）

※矢印は無情報を基準にして有意に変動したことを示す 


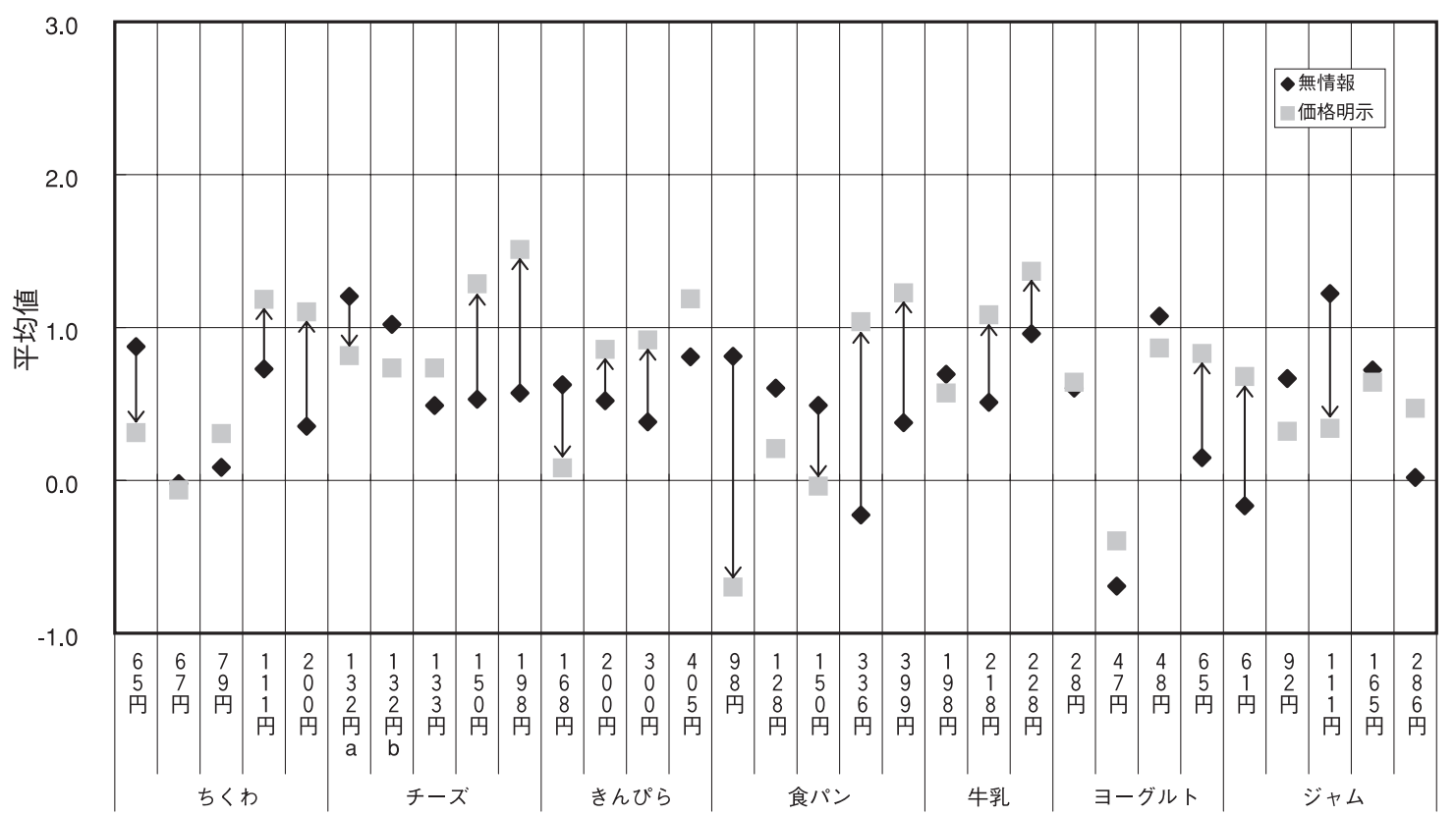

図 3 無情報と価格情報明示での評価の变動（主食·䊍菜·その他）

※矢印は無情報を基準にして有意に変動したことを示す

無情報と比較して最も安価な 132 円 a は $5 \%$ 危険率で無 情報より有意に評価が低くなった。前述のバウムクーへ ン同様に 132 円は a · b の 2 種類あり, 外観に若干差異 があるため評価の変動も異なったと考えられた。最も高 価な198円及び 2 番目に高価な 150 円は $0.1 \%$ 危険率で有 意に評価が高くなった。きんぴらについては, 最も安価 な 168 円は $5 \%$ 危険率で無情報より有意に評価が低くな った。また中間価格の 200 円は $1 \%$ ，300円は $5 \%$ 危険率 で価格明示のほうが有意に評価が高くなった。食パンに ついては，最も安価な 98 円と中間価格の 150 円が $5 \%$ 危 険率で無情報より有意に評価が低くなり，2 番目に高価 な336円と最も高価な399円は0.1\%危険率で有意に評価 が高くなった。牛乳については, 228円が $5 \%$ 危険率, 218円が0.1\%危険率で無情報より有意に評価が高くなっ た。ヨーグルトについては最も高価な 65 円は無情報より $1 \%$ 危険率で有意差が認められ, 評価が高くなった。ジ ヤムについては，111円は0.1\%危険率で無情報より有意 に評価が低く，また 61 円は $1 \%$ 危険率で無情報より有意 に評価が高くなった。

主菜・惣菜・その他の食品について価格を明示した場 合の変化をまとめると, 31品中情報によって評価が有意 に変化したのは18品約 $58 \%$ であった。

\section{(2) 商品名明示の影響}

調味料一調味料の結果を図 4 に示した。酢については, $\mathrm{UJ}$ 特選本造が $5 \%$ 危険率, 他の 4 品が $0.1 \%$ 危険率で 5 品全てが無情報より有意に評価が高くなった。塩でも, 中国 S 省産岩塩とM深層海水が $5 \%$ 危険率, $\mathrm{H}$ の塩が 1 $\%$ 危険率， $\mathrm{A}$ 塩と ON 天然塩が $0.1 \%$ 危険率で 5 品全て
が無情報より有意に評価が高くなった。奨油については

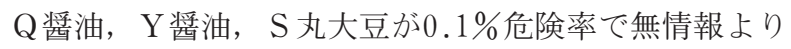
有意に評価が高くなった。味増については, NK 純正が $5 \%$ 危険率, NK 天然醸造が $1 \%$, 他の 3 品が $0.1 \%$ 危 険率で 5 品全て無情報に比べ有意に評価が高くなった。 砂糖については, 無農薬栽培が 1 \%危険率で無情報より 有意に評価が低くなった。また三温糖が $5 \%$ 危険率, て んさい含蜜が $0.1 \%$ 危険率で無情報より有意に評価が高 くなった。みりんについては, 家醸が $0.1 \%$ 危険率で無 情報に比べ有意に評価が高くなった。マヨネーズについ ては，Qが0.1\%危険率で無情報より有意に評価が高く なった。ドレッシングについては，Eが $0.1 \%$ 危険率で 無情報に比べ有意に評価が低くなった。FSが $5 \%$ 危険 率, Qが $0.1 \%$ 危険率で無情報に比べ有意に評価が高く なった。

調味料について商品名を明示した場合の变化をまとめ ると, 39品中情報によって評価が有意に変化したのは 24 品で約 $62 \%$ であった。調味料は, 有名な商品名が既知で あるということよりは, 「本醸造」「深層海水」「天然醸 造」等の形容語がついているものが無情報と比較し評価 が高くなる傾向がみられた。

飲料·菓子類一飲料 · 菓子類の結果を図 5 に示した。 みかん缶詰については，M屋が $1 \%$ 危険率， IB が $0.1 \%$ 危険率で無情報より有意に評価が高くなった。カステラ については，X円均一が $5 \%$ 危険率で無情報より有意に 評価が低くなった。また $\mathrm{CP}$ が $1 \%$ 危険率, $\mathrm{AJ}$ と B 堂 が $0.1 \%$ 危険率で無情報より有意に評価が高くなった。 バームクーヘンについては MS 屋と UHM が $5 \%$ 危険 率，K屋が $0.1 \%$ 危険率で無情報より有意に評価が高く

$190(96)$ 


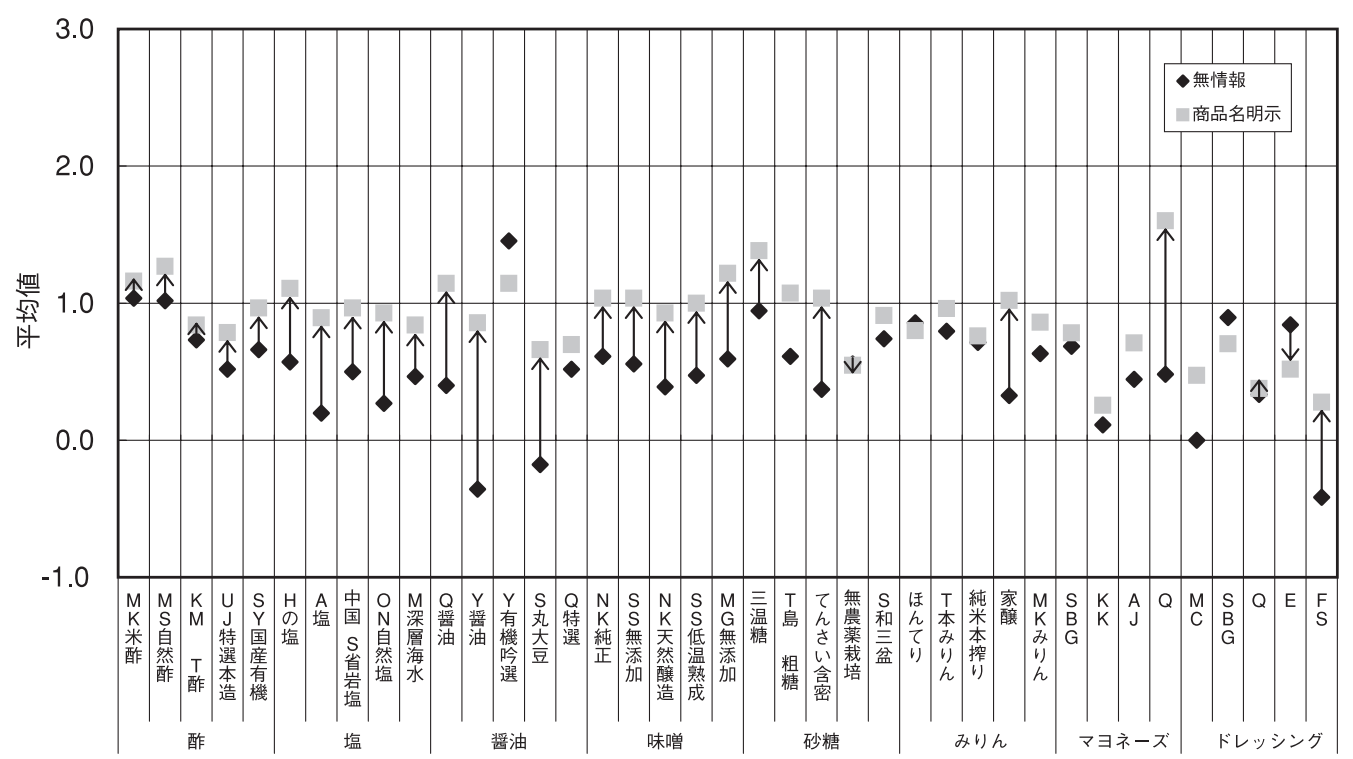

図 4 無情報と商品名情報明示での評価の変動（調味料）

※矢印は無情報を基準にして有意に変動したことを示す

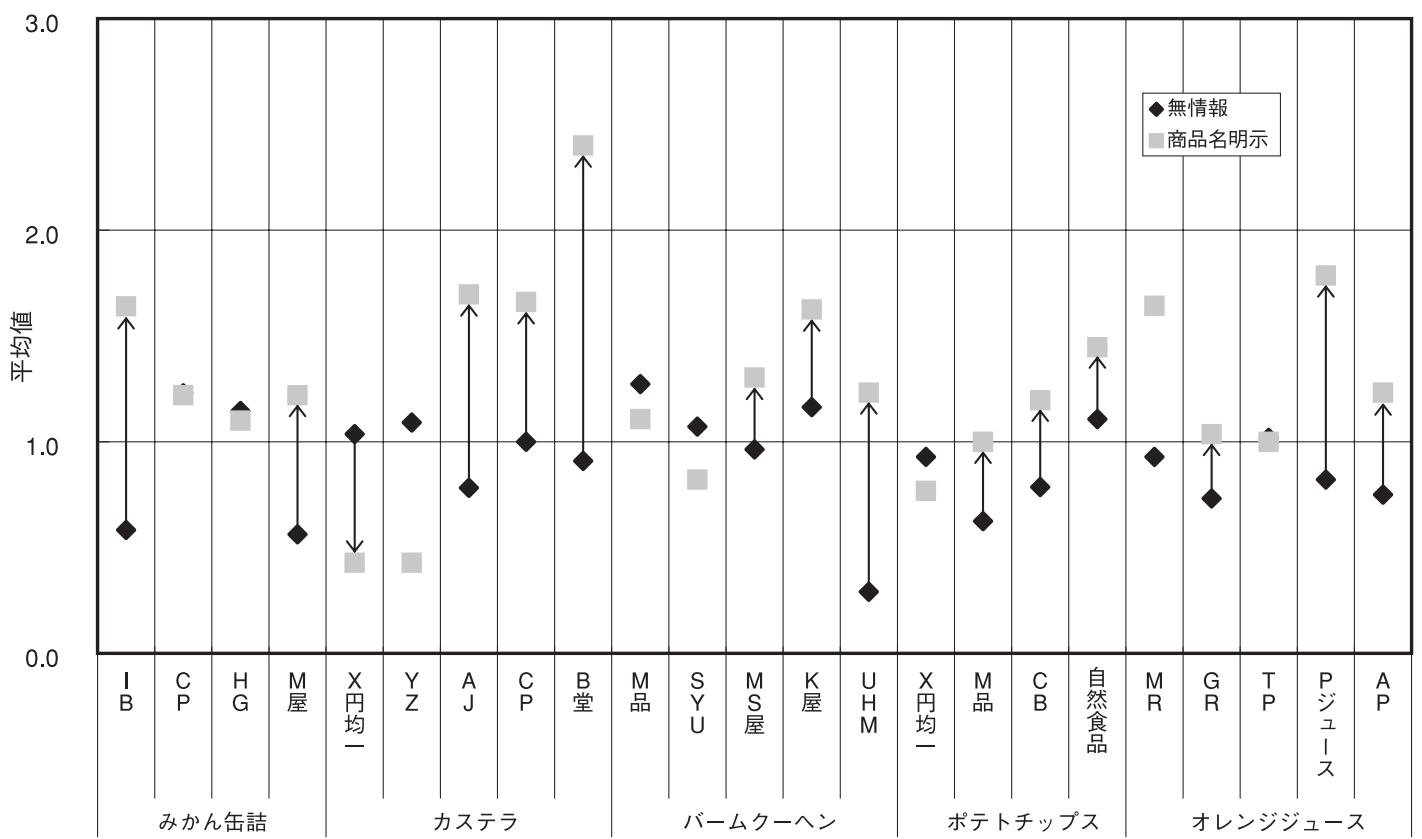

図 5 無情報と商品名情報明示での評価の変動（飲料·菓子）

※矢印は無情報を基準にして有意に変動したことを示す

なった。ポテトチップスについては， $\mathrm{M}$ 品， $\mathrm{CB}$, 自然 食品が $5 \%$ 危険率で無情報より有意に評価が高くなった。 オレンジジュースについては, AP が $5 \%$ 危険率, GR と Pジュースが $0.1 \%$ 危険率で無情報より有意に評価が 高くなった。

飲料・菓子類について商品名を明示した場合の变化を まとめると，23品中情報によって評価が有意に変化した のは15品約65\%であった。みかん缶詰の M屋，カステラ の $\mathrm{B}$ 堂，ポテトチップスの $\mathrm{CB}$ ，オレンジジュースの $\mathrm{P}$ ジュースなどのように，商品と商品名が周知のものでは，
商品名明示で評価が有意に高くなった。また，商品名に 自然食品と称するポテトチップスでも評価が有意に高く なったのは，商品名から安全性が感じられたのであろう。

主食·制菜·その他の食品一主食·制菜·その他の食 品の結果を図 6 に示した。ちくわについては, デパート は $5 \%$ 危険率で無情報より有意に評価が低くなった。 NS と CP とスーパーが $1 \%$ 危険率で無情報より有意に 評価が高くなった。チーズについては CP が $5 \%$ 危険率 で，MJ と専門店 F が $0.1 \%$ 危険率で無情報より有意に 評価が高くなった。きんぴらについては，スーパーは 5 


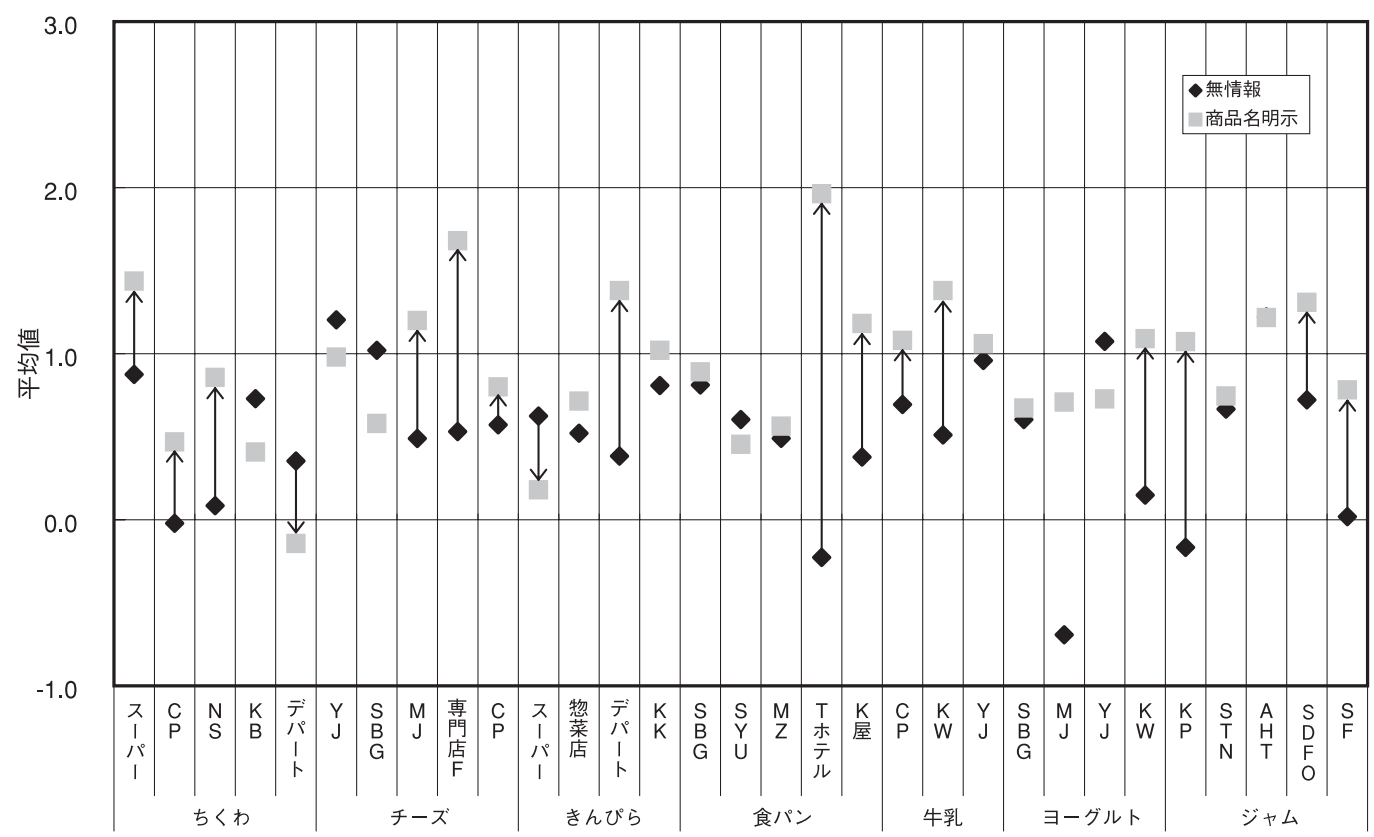

図 6 無情報と商品名情報明示での評価の変動（主食·制菜·その他） ※矢印は無情報を基準にして有意に変動したことを示す

\%危険率で無情報より有意に評価が低くなり，デパート が $0.1 \%$ 危険率で無情報より有意に評価が高くなった。 食パンについては，Tホテルと $\mathrm{K}$ 屋が $0.1 \%$ 危険率で無 情報より有意に評価が高くなった。牛乳については CP が $5 \%$ 危険率，KW が $0.1 \%$ 危険率で無情報より有意に 評価が高くなった。ヨーグルトについては $\mathrm{KW}$ が $0.1 \%$ 危険率で無情報より有意に評価が高くなった。ジャムに ついては, SDFO と SFが $1 \%$ 危険率で, KPが0.1\% 危険率で無情報より有意に評価が高くなった。

主食・惣菜·その他の食品について商品名を明示した 場合の变化をまとめると，31品中情報によって評価が有 意に変化したのは17品約55\%であった。商品名明示で評 価が低くなったのは,ちくわのデパート,きんぴらのスー パーであった。一方ちくわの NS，牛乳とヨーグルトの

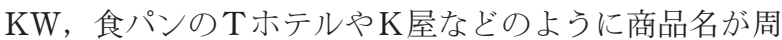
知のものでは，商品名明示で有意に評価が高まったもの が多い。また価格明示の場合と比較し，商品名明示の場 合のほうが評価が高くなる傾向がみられた。

\section{（3） 産地・購入場所の影響}

産地・購入場所の影響の結果を図 7 に示した。パイナ ップル缶詰については，インドネシアは無情報より評価 が低くなり $5 \%$ 危険率で有意差が認められ，八ワイは $0.1 \%$ 危険率で無情報より評価が高くなり有意差が認め られた。みかん缶詰については，中国産は評価が低くな り無情報と情報明示に $0.1 \%$ 危険率で有意差が認められ， 国産は $0.1 \%$ 危険率で無情報より有意に評価が高くなっ た。りんごについては，産地の記載がないものは無情報 より評価が低くなり $0.1 \%$ 危険率で有意差が認められ，
青森産は0.1\%危険率で，長野産は $1 \%$ 危険率で無情報 より評価が高くなり有意差が認められた。りんごジュー スについては，国産も輸入もいずれも $0.1 \%$ 危険率で無 情報より有意に評価が低くなったが，輸入の低下が大き かった。オレンジジュースについては，愛媛県は無情報 より評価が高くなり $0.1 \%$ 危険率で有意差が認められた。 ピーナツについては，中国産は無情報より評価が低くな り $5 \%$ 危険率で有意差が認められたが日本産は大きな変 化はなかった。クッキーについては国産では無情報より 評価が高くなり $0.1 \%$ 危険率で有意差が認められた。チ ョコレートについては，ベネズエラが $5 \%$ 危険率で無情 報より有意に評価が低くなり，ベルギーが $5 \%$ の危険率 で無情報より評価が高くなり有意差が認められた。チー ズについては，デンマーク，ドイッが $1 \%$ 危険率，フラ ンスが $5 \%$ 危険率で無情報より有意に評価が高くなった。 主食の白飯については，ST が $5 \%$ 危険率で無情報より 有意に評価が低くなり，また有機栽培は $0.1 \%$ 危険率, UN 産は $5 \%$ 危険率で無情報より有意に評価が高くなっ た。うずら豆の購入店の違いでは，スーパーで購入した ものと，デパート惣菜専門店で購入したものでは無情報 より評価が高くなり両者とも5\%危険率で有意差が認め られた。

産地・購入場所について産地・購入場所を明示した場 合の変化をまとめると，情報で評価に変化がみられたも のは30品中 22 品約 $73 \%$ であった。オレンジジュースの愛 媛産, りんごの青森産と長野産, チョコレートのベルギー 産のように産地が既知であること, また国産は外国産に 比べて評価が高まる傾向がみられた。

$192(98)$ 


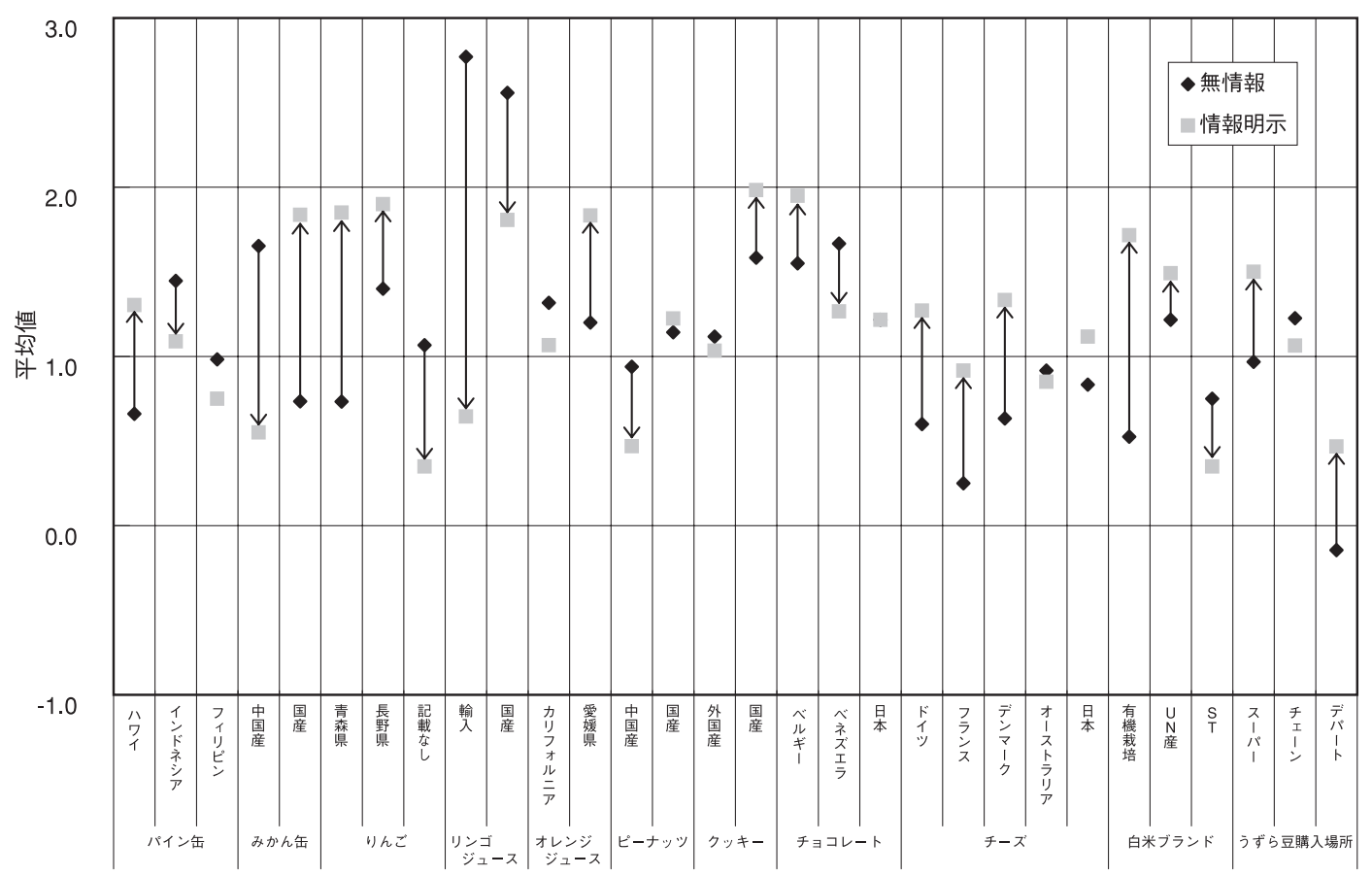

図 7 無情報と産地・購入場所情報明示での評価の変動

※矢印は無情報を基準にして有意に変動したことを示す

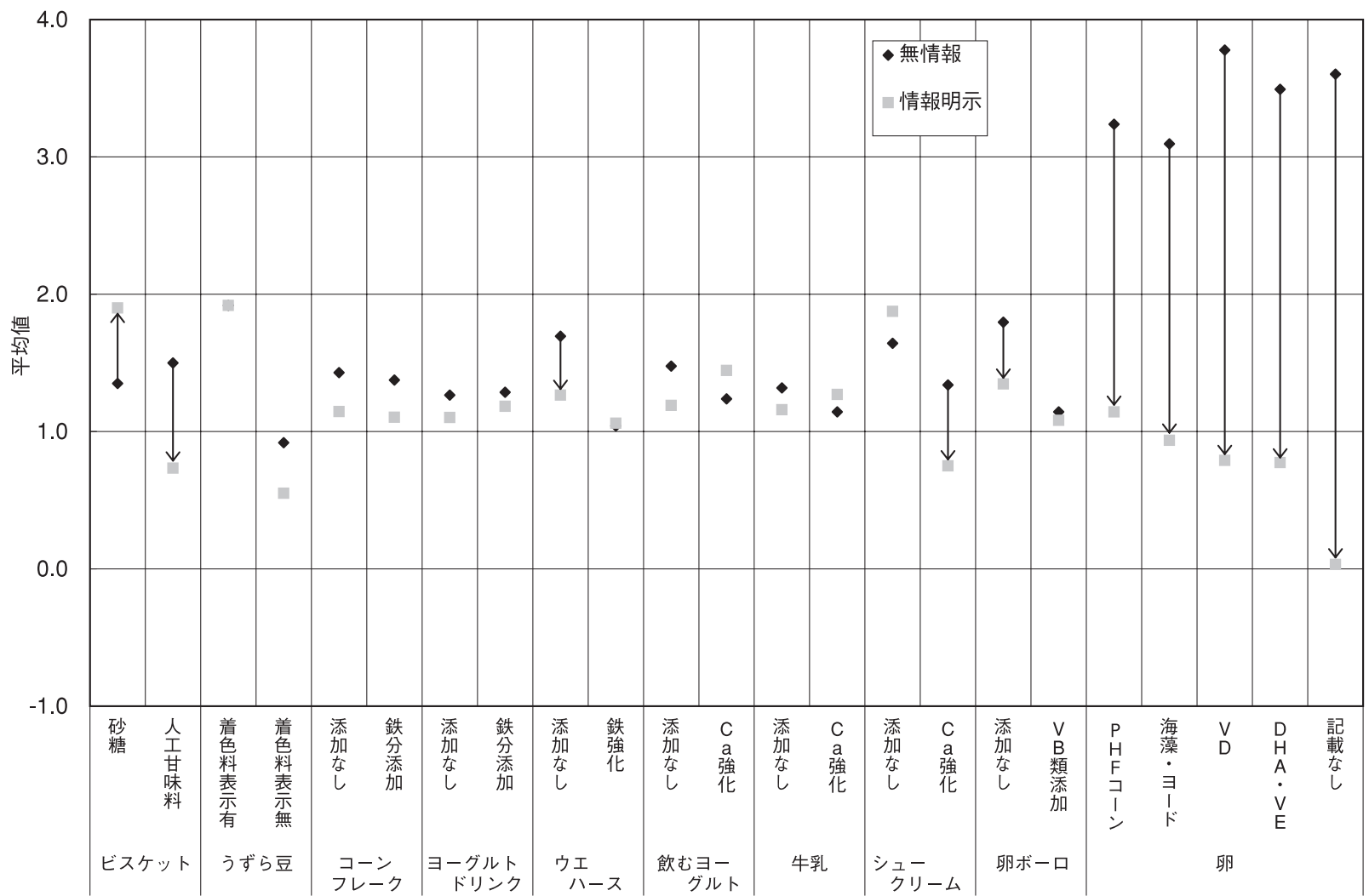

図 8 無情報と栄養成分·添加物情報明示での評価の変動

※矢印は無情報を基準にして有意に変動したことを示す

\section{（4）栄養成分・添加物の影響}

栄養成分・添加物の結果を図 8 に示した。ビスケット に添加した甘味料のちがいについては，人工甘味料使用
は評価が低くなり $0.1 \%$ 危険率で有意差が認められ，砂 糖使用は情報明示で $0.1 \%$ 危険率で無情報より有意に評 価が高くなった。うずら豆の煮物の着色料の使用につい 
ては，着色料不使用の表示があるものも着色料使用の表 示がないものも無情報と情報明示で差は認められなかっ た。鉄分添加のコーンフレークの栄養成分添加について は，鉄分添加なしも鉄分添加も無情報より評価を下げた が有意差は認められなかった。ヨーグルトドリンクにつ いても，鉄分添加なし，鉄分添加のどちらも有意差は認 められなかった。ウエハースについては, 無情報より栄 養成分添加なしが評価が下がり $1 \%$ 危険率で有意差が認 められたが，鉄分強化のものは無情報と情報明示間に有 意差は認められなかった。カルシウム添加の飲むヨーグ ルト・牛乳については, 無情報と情報明示時に有意差は 認められなかった。シュークリームでは，カルシウム強 化が評価が低くなり $1 \%$ 危険率で有意差が認められた。 ビタミン添加のタマゴボーロについては，栄養成分添加 なしは $1 \%$ 危険率で無情報より有意に評価が低くなった が，ビタミン $\mathrm{B}_{1}$ と $\mathrm{B}_{2}$ 添加ありは評価に変化はなかった。 また，ヨード含むなどの添加物のある卵については，5 品目全てで無情報より評価が下がり $0.1 \%$ 危険率で有意 差が認められた。

栄養成分・添加物について栄養成分・添加物名を明示 した場合の結果ををとめると, 栄養成分添加の情報は, おいしさにあまり良い影響は与えず，むしろ評価が低く なる傾向がみられた。

\section{（5）遺伝子組み換え・栽培方法の影響}

遺伝子組久換え・栽培方法の結果を図 9 に示した。遺 伝子組換えについては，コーン缶詰では遺伝子組み換え の表示がないものは無情報より評価は低くなり $0.1 \%$ 危 険率で有意差が認められた。原材料が遺伝子組久換えで はないと表示されているものは無情報より評価が高くな
り $1 \%$ 危険率で有意差が認められた。大豆水者について は，原材料が遺伝子組み換え有りと表示されているもの は無情報より評価が低くなり 1 \%危険率で有意差が認め られた。トマトケチャップ・ポップコーンについては, 無情報と情報明示時に有意差は認められなかった。ポテ トチップスについては遺伝子組み換えの表示がないもの は0.1\%危険率で無情報より有意に評価が低くなり，遺 伝子組久換えではないと表示されているものは無情報よ り $1 \%$ 危険率で有意に評価が高くなった。冷凍枝豆・餡 については，無情報と情報明示で有意差は認められなか った。コーンスナックについては, 遺伝子組み換えの表 示がないものは無情報より評価が低くなり $0.1 \%$ 危険率 で有意差が認められた。遺伝子組み換え無しと表示され ているものは無情報より評価が高くなり $5 \%$ 危険率で有 意差が認められた。羊美については，遺伝子組み換えに 関する情報が記載されていないものは無情報より評価が 低くなり 1 \%危険率で有意差が認められた。遺伝子組み 換え無しと表示されているものは，無情報より評価が高 くなり $5 \%$ 危険率で有意差が認められた。

栽培方法についてはミニトマトとかぼちゃについて質 問した。ミニトマトについては, 栽培方法表示のないト マトは評価が低くなったが有意差は認められなかった。 減農薬と表示したミニトマトは評価が高くなり無情報と 情報明示間に $5 \%$ 危険率で有意差が認められた。かぼち ゃについては, 無農薬有機野菜と明示したものは評価が 高くなり $1 \%$ 危険率で有意差が認められた。

遺伝子組み換えについて原材料が遺伝子組み換えして いないと表示のあるもの，遺伝子組み換えをしていると 表示のあるもの，遺伝子組み換えの情報が表示されてい ないものについての結果をまとめると，原材料が遺伝子

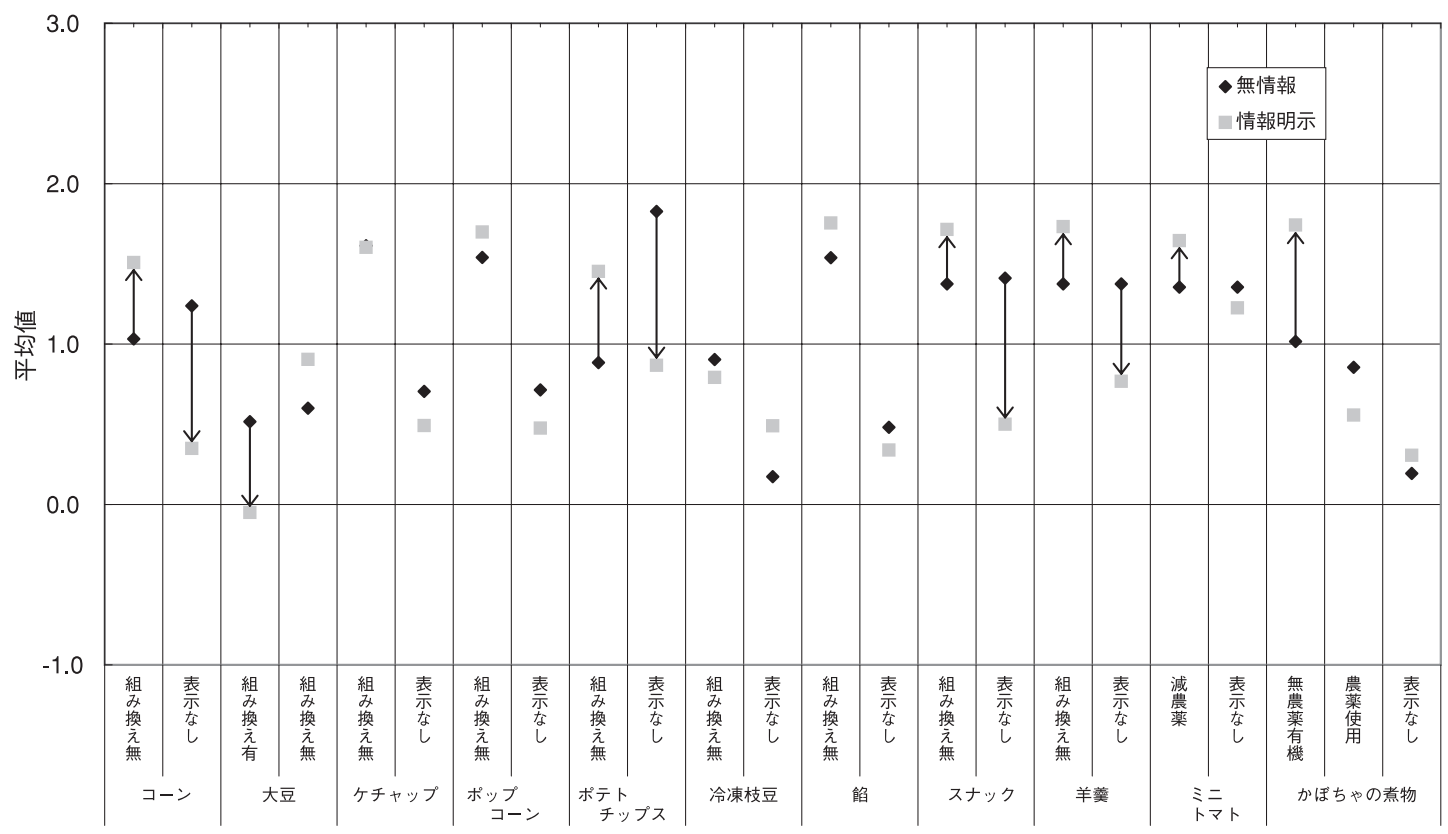

図 9 無情報と遺伝子組換え・栽培方法情報明示での評価の変動 ※矢印は無情報を基準にして有意に変動したことを示す

194 (100) 
組み換えしていないと表示のあるもののほうが遺伝子組 久換えの情報が表示されていないものと比較し無情報よ り情報明示で評価が高くなる場合が若干多かった。反対 に，評価が下がったのは遺伝子組み換え原材料の使用を 明示していないものがほとんどであった。また栽培方法 については「減農薬」「無農薬有機」など良いイメージ をもたれているものについては評価が高い傾向がみられ た。

産地・栄養成分・添加物・遺伝子組久換え・栽培方法 の情報では, 全76品中情報によって評価が変化した品数 は43で約57\%であった。

以上のように，情報を明示したことによって評価が高 まるものと低下するものとがあり，情報はおいしさの評 価に影響を与えることが示唆された。

\section{（6）試食による評価}

食パンとヨーグルトについて，試食した。結果を図10 に示した。食パンの価格については，中間的な価格であ る128円が無情報より価格明示のほうが $0.1 \%$ 危険率で有 意に拈いしいとされた。食パンの商品名明示については， Tホテルが無情報より商品名明示で $0.1 \%$ 危険率で有意 に評価が高くなり，SBG が逆に0.1\%危険率で有意に評 価が低くなった。

ヨーグルトの価格については，最も高価な65円が無情 報より価格明示で $0.1 \%$ 危険率で有意に評価が高くなり， 最も安価な 28 円が有意に評価が低くなった。ヨーグルト の商品名明示については, $\mathrm{KW}$ と $\mathrm{MJ}$ が無情報より商 品名明示で $0.1 \%$ 危険率で有意に評価が高くなり，SBG は $0.1 \%$ 危険率で有意に評価が低くなった。

目視して評価した場合と試食により評価した場合とは 同じ傾向を示し，実際に食べることなく情報に接するだ
けで食物のおいしさの評価が変化することが確認された。 食物のおいしさとは何かを多面的に考えるにあたっては， 官能評価において情報の影響を全く排除してよいか否か について検討の余地があると考えられた。

\section{4. 要約}

同一食品に対して，情報を与えない場合と情報を与え た場合とで扔いしさの印象がどのように变化するかを官 能評価法により検討した。情報は, 価格, 商品名, 産地, 購入場所, 添加物, 栄養成分, 遺伝子組久換え, 栽培方 法である。評価の方法は, 検査台に置いた食品について 目視により拈いしさを判断することとし， 7 段階の評点 法で評価した。また目視による評価の信憑性を確認する ため食パンとヨーグルトの 2 品目については実際に試食 した。

1. 価格については, 調査品目数 94 品のうち約 $51 \%$ に ついて，無情報の場合より価格明示した場合で有意に評 価の変化が認められた。高価なものは情報明示で評価が 高まり，安価なものは評価が低くなる傾向がみられた。

2. 商品名については, 調査品目数 94 品のうち約 $61 \%$ について，無情報と商品名明示で有意差が認められた。 調味料では,「本醸造」「深層海水」「天然醸造」などの 表示があるものの評価が高くなる傾向がみられた。また， 価格明示より商品名明示で評価が高くなる品目が多かっ た。

3 、産地については, 評価に変化がみられたものは調 査品目数30品のうち約 $73 \%$ であった。オレンジジュース の愛媛産, チョコレートのベルギー産, りんごの青森産, 長野産のように産地が既知である品目は評価が高くなる 傾向がみられた。

4. 栄養成分 ·添加物については, 栄養成分添加の情

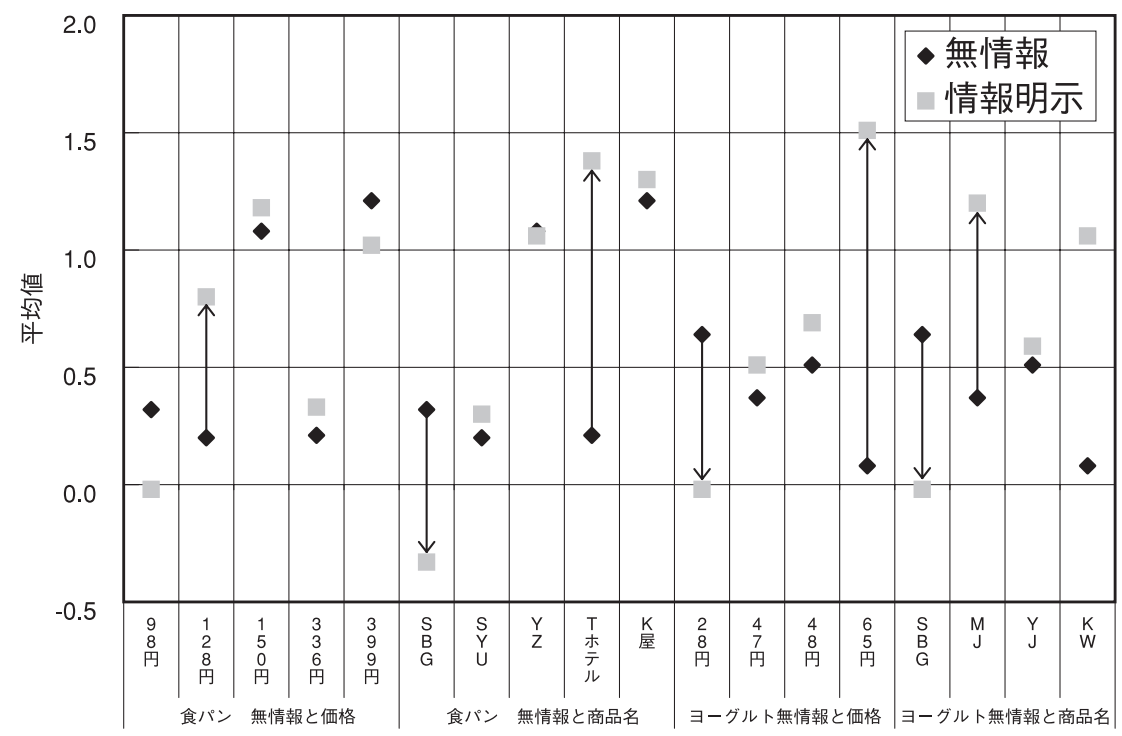

図10 試食した食品（食パン・ヨーグルト）/無情報と価格情報明示及び商品名情報明示での評価の変動 ※矢印は無情報を基準にして有意に変動したことを示す 
報は，おいしさにあまり良い影響は与えず，むしろ評価 が低くなる傾向がみられた。評価が下がったのは, 調査 品目数 23 品のうち約 $39 \%$ であった。

5. 遺伝子組み換えでは, 原材料が遺伝子組み換え無 しと表示されているもののほうが遺伝子組久換えに関す る情報が表示されていないものより情報を与えて評価が 高くなる場合が若干多かった。また「減農薬」「無農薬 有機」など一般に良いイメージをもたれているものは評 価が高い傾向にあった。情報で評価に変化がみられたも のは23品中 11 品 $48 \%$ であった。

6. 実際に試食した食パンとヨーグルトについても情 報を与えることによって評価が変化し, 目視して評価し た場合とほぼ同じ傾向を示した。

本調査結果から, 何らかの情報を与えると, 食品の種 類や情報の種類によって評価に変化が生じることが明ら かとなった。

本研究は, 財団法人アサヒビール学術振興財団の研究 助成を受けた。

\section{参考文献}

1）小西史子, 坂元明子：日本家政学会誌, Vol.53, No. 2, 205-211 (2002)

2) 柳本正勝：日本調理科学会誌, Vol.35, No. 1, 32-36 (2002)

3）大谷貴美子, 饗庭照美, 徳田涼子, 尾崎彩子, 南出隆久： 日本調理科学会誌, Vol.34, No.3, 270-275 (2001)

4) Wansink B, Painter JE, North J: Obes Res., Vol.13, No. 1, 93-100 (2005)

5) Tuorila H, Meiselman HL, Bell R, Cardello AV, Johnson W: Appetite, Vol.23, No.3, 231-246 (1994)

6) Meiselman HL ,Hedderley D, Staddon SL, Pierson BJ, Symonds CR: Appetite, Vol.23, No. 1, 43-55 (1994)

7) Marcelino AS, Adam AS, Couronne T, Koster EP, Sieffermann JM: Appetite, Vol.36, No. 1, 9-14 (2001)

8）高橋久仁子: 群馬大学教育学部紀要, 芸術 ·技術 ·体育 生活科学編, 第34巻, 213-228（1999）

9) 高橋久仁子: 群馬大学教育学部紀要, 芸術 ·技術 - 体育 生活科学編, 第33巻, 235-249（1998） 